\title{
CRM and its Importance for Business Competitiveness
}

\author{
Peter Stuchlý1, Roderik Virágh ${ }^{1}$, Marcela Hallová ${ }^{1}$, Edita Šilerová ${ }^{2}$ \\ ${ }^{1}$ Faculty of Economics and Management, Slovak University of Agriculture in Nitra, Slovakia \\ ${ }^{2}$ Faculty of Economics and Management, Czech University of Life Sciences Prague, Czech Republic
}

\begin{abstract}
This paper deals with the Customer Relationship Management (CRM) system with emphasis on the importance for the competitiveness of a business. The aim of the present article is to seek whether a business pursues customer value on a regular basis regardless of its size. Monitoring customer value can thus be one of the criteria that measure the success of implementing an overall customer relationship management concept in a particular business. CRM system is also used in agribusiness.
\end{abstract}

\section{Keywords}

CRM systems, CRM implementation criteria, customer value, business size, agribusiness, competitiveness.

Stuchlý, P., Virágh, R., Hallová, M. and Šilerová, E. (2020) “CRM and its Importance for Business Competitiveness", AGRIS on-line Papers in Economics and Informatics, Vol. 12, No. 1, pp. 93-98. ISSN 1804-1930. DOI 10.7160/aol.2020.120108.

\section{Introduction}

As claimed by Látečková et al. (2018) the development of information and communication technologies (ICT) is currently conditioned by the development of industry, society and many other factors. ICT play important roles in the development of enterprises and automation of their processes. The deployment of information systems and information technology as claimed by Hallova and Hanova (2019) has become a prerequisite for the success of businesses in all areas of economic activity today. Information available from business data enables managers and employees to make quick and accurate decisions so they can efficiently manage operations and respond quickly to business opportunities or threats. Wessling (2003) claims that CRM is not a new philosophy in relation to customers, nor is it a breakthrough and omniscient information technology. It is a comprehensive methodology of creating economically advantageous and beneficial relationships with customers with an emphasis on targeted qualification of personnel, methods of social psychology and interaction. Mccarthy and Perreault (1995) claim that the focus of our attention is on the customer whose relationship with the business is to be organized. Also, Goldenberg, (2008) defines CRM as an approach of a business that integrates people, processes and technologies towards maximizing customer relationships, or as a system that is increasingly using the Internet to provide the closest possible coordination with customers. In CRM, quality is important, as stated by Kretter (2008), which directly affects a product or service. Quality can be defined as "independence from errors". Customeroriented businesses orient quality in accordance with customer satisfaction. Šimek et al. (2008) state that any long-term relationship must be based on mutually beneficial cooperation. Starting the CRM implementation process as claimed by Storback and Lehtinen (2002) must therefore be based on the established strategy of the business, what means consistently analyse existing business processes and metrics, by means of which we identify and serve the customer and check whether the business relationship is really mutually beneficial.

Vaněk et al. (2011) argue that the benefits of CRM can be seen in streamlining processes and providing sales representatives, marketing and management with better, more detailed customer information. Depending on the area of application, we distinguish CRM into four basic groups: 1 . Active CRM, 2. Operational CRM, 3. Collaborative CRM, 4. Analytical CRM. (Novotný et al., 2010). Active CRM as claimed by Pour et al. (2015) is based on an active centralized database that supports process automation. 
Operational CRM provides support for business processes (also called front office). Every contact or action with a customer is recorded in his history, which is recorded by CRM and each company employee can draw from this database of history and use the information about the customer for further work with such customer. Cooperative CRM covers direct contact with the customer. It contains various communication channels, not only the Internet, but also IVR (Interactive Voice Response), which is an automated answer for telephone communications. Analytical CRM analyses customer data. These analyses are targeted to:

- designing and implementing targeted marketing activities and campaigns leading to higher efficiency,

- customer behaviour analysis is used to support decision making on products and services (e.g. setting appropriate prices),

- management decisions such as financial forecasts or customer profitability analysis.

Lošt'áková et al. (2009) state that choosing the right CRM strategy is an important decision. Recently, three types of CRM strategy have been implemented: The first level of customer relationship marketing is called mass personalization, where an individual customer is identified by name, address, or previous purchases.

This information is then used to create a system of individual marketing communication with target customers, so they have the impression that the company cares about them individually, even though they are offered standard products Janšto et al. (2019). Therefore, a certain level of database marketing is of course necessary. This strategy is widely used by banking institutions and mail order businesses. Another type, as Basl and Blažíček (2008) claim, is mass customization, which is based on the fact that some customers are willing to pay more for the special benefits they can co-create to some extent. Customers have the impression that they have the option of using premium services while choosing from a standard range. This strategy is used by furniture manufacturers on a modular principle. Differentiated customization respects the different needs and requirements of customers and they have "tailored" not only products or services, but also the way of distribution and communication - the entire marketing mix. This strategy emphasizes close cooperation among entities.

Bruhn and Mahyera (2003) argue that striving to respect different customer needs and wishes is part of a differentiated strategy. Individual products are tailored to each customer. There is close cooperation between the manufacturer and its customer. Value for the customer is created on the basis of mutual relationship. The strategy is used in $\mathrm{B} 2 \mathrm{~B}$ or $\mathrm{B} 2 \mathrm{C}$ markets. The term B-2-B refers to business relationships and communication between two commercial companies that do not serve end-users on a mass scale. An important feature of the B-2-B model is, as stated by Zairi and Sinclair (1995), a greater emphasis on logistics and business provision than on customer acquisition compared to B-2-C. The term Businessto-Consumer (B-2-C), as claimed by Lošt'áková et al. (2009), is used to identify business relationships and communications between business and end customers. They are realized by web applications, virtual shops on the Internet etc. Online business on the Internet, i.e. sale of goods, information, services and advertising space to end customers. The term Consumer-toBusiness (C-2-B), as claimed by Burnett (2005), is used to designate shops in which a commercial transaction is initiated by a buyer wishing to obtain the best possible prices. The customer creates a request (demand) for a specific product at the proposed price. In return, the business partner will tell him if he is willing to accept this request.

The link between the information system and the business process, as claimed by Goldenberg (2008), is confirmed in the implementation of business information systems by the necessity to perform an "inventory" and to change all processes in the company affected by the new information system. Loštáková et al. (2009) claims that in today's companies, it is almost all areas ranging from logistics, sales and technical departments, to employee records and all related activities - remuneration of merchants based on delivered goods, remuneration of technical workers based on repairs and installations performed, remuneration for BackOffice employees for their activities, to quantify all work and results in the form of reports in the hands of management. The result is not only to achieve better data availability, but also to the way and thus the processes that acquire and handle the data. Finally, this symbiosis of information systems with processes as claimed by Janšto et al. (2019) is also evidenced by foreign surveys, which show that the introduction of ERP systems, in addition to reducing costs and increasing quality, has made room for easier decision-making in managing and deciding on customer requirements and hence improving processes throughout the business. 


\section{Materials and methods}

We solved this project between January 2019 and July 2019 and found out the following information. About 80 agricultural enterprises from western Slovakia were addressed. Only 43 questionnaires were filled in and returned. However, after checking and verifying the questionnaire information, only 39 questionnaires were included in the sample. Businesses were categorized according to the number of employees (Table 1).

\begin{tabular}{|l|c|c|c|}
\hline Business category & $\begin{array}{c}\text { Number } \\
\text { of employees }\end{array}$ & $\begin{array}{c}\text { Number } \\
\text { of businesses }\end{array}$ & $\begin{array}{c}\% \\
\text { ofbusinesses }\end{array}$ \\
\hline Micro business & 1 to 9 & 15 & 38.46 \\
\hline Small business & 10 to 49 & 13 & 33.34 \\
\hline Medium business & 50 to 249 & 11 & 28.20 \\
\hline
\end{tabular}

Source: own elaboration

Table 1: Categories of businesses by number of employees.

Businesses are divided equally into three groups of micro, small and medium according to the number of employees. The sample is representative and takes into account the actual numbers of such large businesses (Figure 1).

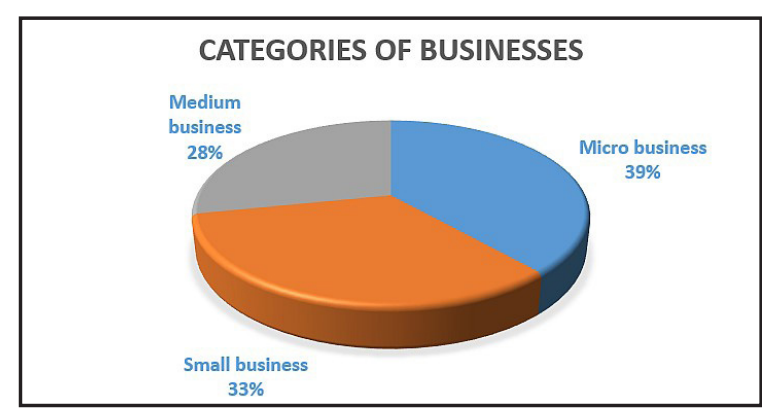

Source: own elaboration

Figure 1: Division of businesses by category.

The questionnaire survey also examined the dominant sector. We investigated whether they are B-2-B (business to business) or B-2-C (business to customer) businesses. From the questionnaire it was found that 24 agribusinesses representing almost $61.5 \%$ of all respondents are engaged in trading with other businesses (the so-called B-2-B) and 15 agricultural enterprises representing almost $38.5 \%$ of respondents focusing on trading with end customers (the so-called B-2-C) (Table 2, Fifure 2).

\begin{tabular}{|l|c|c|}
\hline Dominant industry & $\begin{array}{c}\text { Number } \\
\text { of businesses }\end{array}$ & \% of businesses \\
\hline B-2-B & 24 & 61.5 \\
\hline B-2-C & 15 & 38.5 \\
\hline
\end{tabular}

Source: own elaboration

Table 2: Dominant industry.

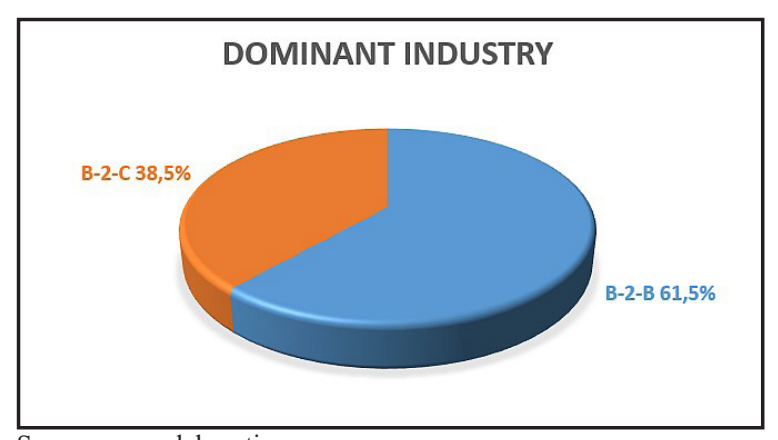

Source: own elaboration

Figure 2: Breakdown of businesses by dominant sector.

In the questionnaire we examined the existence of dependence on individual questions. We used statistical methods to investigate the normality of the population distribution. These are skew and excess tests and, in the event of uncertainty, the Jarque-Berra test.

The skew and excess tests test the null hypothesis that random sampling comes from a population with a normal probability distribution of $\mathrm{N}(\mu, \sigma)$. In this case, both the skew and the excess coefficients of the normal distribution are equal to zero, so estimates should also be close to zero.

$$
\begin{aligned}
& S_{k}=\frac{\frac{1}{n} \sum(X i-x)^{3}}{\left(\sqrt{\frac{1}{n}} \sum(X i-x)^{2}\right)^{3}} \\
& E_{k}=\frac{\frac{1}{n} \sum(X i-x)^{4}}{\left(\frac{1}{n} \sum(X i-x)^{2}\right)^{2}}-3
\end{aligned}
$$

For dispersion and mean value of these coefficients the following applies:

$$
\begin{aligned}
& E S_{k}=0 \\
& D E_{k}=\frac{24 n(n-2)(n-3)}{(n+1)^{2}(n+3)(n+5)} \\
& E E_{k}=\frac{-6}{(n+1)} \\
& D S_{k}=\frac{6(n-2)}{(n+1)(n+3)}
\end{aligned}
$$

In the skew-based test, we reject the hypothesis about the normal probability distribution of the population if:

$\frac{\left|S_{k}\right|}{\sqrt{D S_{k}}} \supseteq z_{\alpha}$, where $z_{\alpha}$ can be found in the tables $\mathrm{N}(0,1)$ of the probability distribution.

In the excess-based test, the hypothesis about the normality of distribution is rejected if:

$\frac{\left|E_{k}-E E_{k}\right|}{\sqrt{D E_{k}}} \supseteq z_{a}$, where $z_{\alpha}$ can be found in the tables $\mathrm{N}(0,1)$ of the probability distribution. 
The Jarque-Berra test again examines the null hypothesis $\mathrm{H} 0$ that the selected set has a normal probability distribution of $\mathrm{N}(\mu, \sigma)$. To test the hypothesis $\mathrm{H} 0$ we use the following formula:

$\chi=\frac{S_{k}^{2}}{D S_{k}}+\frac{\left(E_{k}-E E_{k}\right)^{2}}{D E_{k}}$

Where $S_{k}$ is the skew selection coefficient and $E_{k}$ is the excess selection coefficient. If the hypothesis H0 holds, $\chi$ has asymptotically $\chi^{2}$ probability distributions with two degrees of freedom. It follows that we reject the hypothesis $\mathrm{H} 0$ if $\chi>\chi_{\alpha, 2}^{2}$.

H0: The business pursues customer value on a regular basis regardless of its size.

\section{Results and discussion}

Firstly, it is necessary to test the normality of the population distribution. Table 2 shows the basic characteristics of data set A, which represents the size of the monitored agricultural enterprises and set $B$, which represents the monitoring of customer value in individual businesses (Table 3 and 4).

\begin{tabular}{|l|c|c|}
\hline Characteristics & Data file A & Data file B \\
\hline Sum of values & 263 & 516 \\
\hline Sampling average & 2.037 & 3.996 \\
\hline Selective variance & 0.718 & 0.953 \\
\hline Standard deviation & 0.868 & 0.986 \\
\hline Minimum value & 1 & 1 \\
\hline Maximum value & 3 & 6 \\
\hline Median & 2 & 4 \\
\hline Modus & 1 & 3 \\
\hline Excess & -1.605 & 0.401 \\
\hline Skew & 0.123 & -0.738 \\
\hline
\end{tabular}

Source: own elaboration

Table 3: Characteristics of data sets A and B.
On the basis of the above, we can say that we reject the hypothesis of the normality of the distribution of the population. We will use a nonparametric independence test to determine the relationship between monitoring value for business customers and its size.

We apply the independence test to a base file with a discrete probability distribution. In this way we test the hypothesis that random variables are independent. The test criterion in this case will be as follows:

$\chi=\sum_{i=1}^{r} \sum_{j=1}^{s} \frac{\left(n_{i j}-\frac{n_{i .} * n_{. j}}{n}\right)^{2}}{\frac{n_{i .} * n_{. j}}{n}}$

Assuming the hypothesis to be valid, the random variable $\chi$ asymptotically $\chi^{2}$ has a probability distribution with (r-1) (s-1) degrees of freedom. It follows that $\mathrm{H} 0$ is rejected if $\chi>\chi_{\alpha,(\mathrm{r}-1)(\mathrm{s}-1)}$.

This test will be based on the data in Table 5 obtained from the questionnaire.

It is clear from the Figure 3 that there is a difference between agricultural enterprises of different sizes in whether they monitor customer value on a regular basis or only irregularly. Most businesses monitor customer value on a regular basis with longer time intervals and/or regularly, allowing them to identify customer needs and improve their goods or services. In order to build a relationship with customers, regular and constant monitoring of customer value is required.

\begin{tabular}{|c|c|c|}
\hline \multicolumn{3}{|c|}{ Test results for normalization of population distribution } \\
\hline & Data file A & Data file B \\
\hline \multicolumn{3}{|c|}{ Skew-based tests } \\
\hline Value & 0.658744 & 3.777547891 \\
\hline \multirow[t]{2}{*}{ Critical value } & 1.96 & 1.96 \\
\hline & $\mathrm{H} 0$ is not denied & H0 denied \\
\hline \multicolumn{3}{|c|}{ Excess-based tests } \\
\hline Value & 3.851269 & 1.124578922 \\
\hline \multirow[t]{2}{*}{ Critical value } & 1.96 & 1.96 \\
\hline & H0 denied & $\mathrm{H} 0$ is not denied \\
\hline \multicolumn{3}{|c|}{ Test of selective combination of skew and excess } \\
\hline Chí & 14.58779 & 13.14788 \\
\hline \multirow[t]{2}{*}{ Critical value } & 10.85 & 10.85 \\
\hline & H0 denied & H0 denied \\
\hline
\end{tabular}




\begin{tabular}{|l|c|c|c|c|c|}
\hline \multirow{2}{*}{ Business size } & \multicolumn{5}{|c|}{ Monitoring Customer Value } \\
\cline { 2 - 6 } & little & irregularly & $\begin{array}{c}\text { regularly, but at } \\
\text { longer intervals }\end{array}$ & regularly & all the time \\
\hline Micro business & 0 & 0 & 5 & 7 & 3 \\
\hline Small business & 0 & 2 & 3 & 6 & 2 \\
\hline Medium business & 0 & 1 & 1 & 4 & 5 \\
\hline
\end{tabular}

Source: own elaboration

Table 5: The business size combined with customer value monitoring.

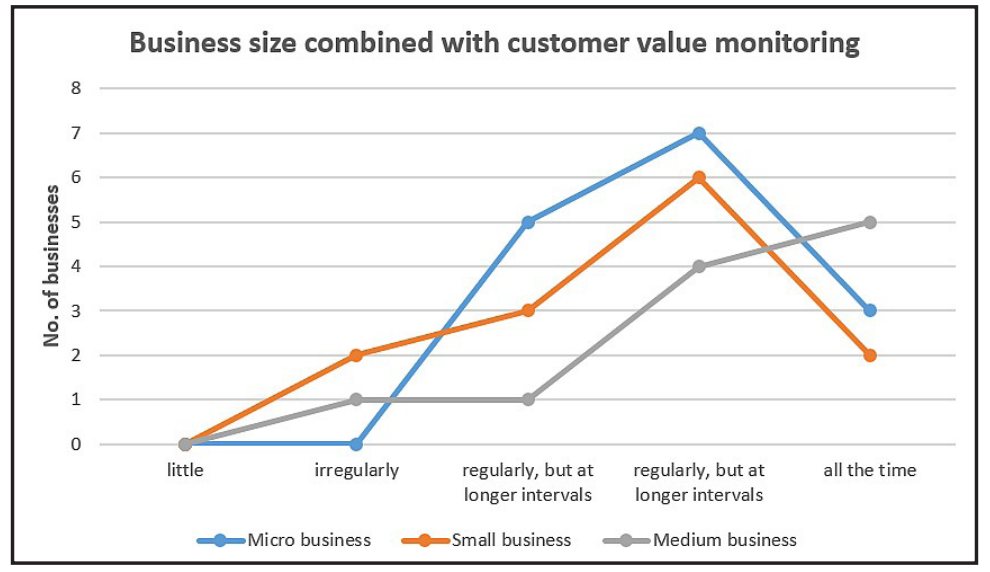

Source: own elaboration

Figure 3: The business size combined with customer value monitoring.

\section{Conclusion}

It was necessary to test the null hypothesis that the size of the business does not affect whether the business regularly monitors customer value. The result of the independence test showed that there is a dependence between the monitored variables. The critical value from the tables is 15.5 and the calculated test criterion value is 22.1699 , i.e., the critical value is less than the test criterion, which means that we reject the null hypothesis and can assert at a 95\% significance level that the size of the business affects whether the business monitors value for the customer at regular intervals.

We also found that most businesses monitor customer value on a regular basis, even $25 \%$ of respondents still monitor it. As mentioned above, this approach allows to identify the customer's needs and improve the goods or services provided to him. It is this approach that can ensure that customers are satisfied with the goods or services provided and to a lesser extent are prone to reach for a competitor's product.

In conclusion, monitoring customer value can thus be one of the criteria that measure the success of implementing an overall customer relationship management concept in a particular agricultural enterprise. It is the monitoring of customer value that becomes one of the competitive advantages in a turbulent environment.

\section{Acknowledgements}

The results and knowledge included herein have been obtained owing to support from the following institutional grant. Internal grant agency of the Faculty of Economics and Management, Czech University of Life Sciences in Prague, grant no. 2019B0009 - "Life Sciences 4.0".

Corresponding authors

Ing. Peter Stuchlý, PhD.

Department of Informatics, Faculty of Economics and Management Slovak University of Agriculture, Tr. A. Hlinku 2, Nitra, 949 01, Slovakia

E-mail:peter.stuchly@uniag.sk 


\section{References}

[1] Basl, J. and Blažíček, R. (2008) "Podnikové informačné systémy“" (in Czech), Prague, Grada. ISBN 978-80-247-2279-5.

[2] Bruhn, M. and Mahyera, A. (2003) "Relationship marketing: management of customer relationships", Harlow, FT Prentice Hall. ISBN 0-273-67601-6.

[3] Burnett, K. (2005) "Klíčoví zákazníci a péče o ne““ (in Czech), Prague, Computer Press, p. 382. ISBN 80-7226-655-1.

[4] Goldenberg, B. J. (2008) “CRM in Real Time“, USA, p. 384. ISBN 978-0-910965-80-4.

[5] Hallová, M. and Hanová M. (2019) "Information and communication technology and their influence on businesses growth in Slovakia", In: EMAN 2019 - economics and management, Belehrad: Association of Economists and Managers of the Balkans, p. 143-148. DOI 10.31410/EMAN.S.P.2019.143.

[6] Janšto, E., Polakovič, P., Hennyeyová, K. and Slováková, I. (2019) "Analysis of the Current Support of E-marketing Activities in Selected Enterprises of the Wine Sector in Slovakia", AGRIS on-line Papers in Economics and Informatics, Vol. 11, No. 4, pp. 31-37. ISSN 1804-1930. DOI 10.7160/aol.2019.110403.

[7] Kretter, A. (2008) "Marketing", Nitra, Slovak University of Agriculture Nitra, p. 286. ISBN 978-80-552-0134-4.

[8] Látečková, A., Bolek, V. and Szabo, L. (2018) "Information systems in agricultural enterprises: An empirical study in Slovak republic", AGRIS on-line Papers in Economics and Informatics, Vol. 10, No. 2, pp. 49-60. ISSN 1804-1930. DOI 10.7160/aol.2018.100205.

[9] Loštáková, H. (2009) “Diferencované ř́zeni vztahů se zákazníky“ (in Czech), Prague, Grada, p. 268. ISBN 978-80-247-3155-1.

[10] McCarthy, J. and Perreault, W. (1995) “Základy marketingu“ (in Czech), Prague, Victoria Publishing. ISBN 80-85605-29-5.

[11] Novotný, O., Pour, J., Maryška and M., Basl, J., (2010) "Řízení výkonnosti podnikové informatiky" (in Czech), Prague, Professional Publishing. ISBN 978-80-7431-040-9.

[12] Pour J., Gála, L. and Šedivá, Z. (2015) "Podniková informatika“ (in Czech), Prague, Grada. ISBN 978-80-247-5457-4.

[13] Storbacka, K., and Lehtinen, J. (2002) "Řizení vztahů se zákazníky" (in Czech), Prague, Grada Publishing, p. 168. ISBN 80-7169-813-10.

[14] Šimek, P., Vaněk, J. and Jarolímek, J. (2008) "Information and communication technologies and multifunctional agri-food systems in the Czech Republic", Plant, Soil and Environment, Vol. 54, No. 12, pp. 547-551. ISSN 1214-1178. DOI 10.17221/426-PSE.

[15] Vaněk, J., Jarolímek, J. and Vogeltanzová, T. (2011) "Information and Communication Technologies for Regional Development in the Czech Republic - Broadband Connectivity in Rural Areas", AGRIS on-line Papers in Economics and Informatics, Vol. 3, No. 3, p. 67-76. ISSN 1804-1930.

[16] Wessling, H. (2003) “Aktivní vztah k zákazníkum pomocí CRM“, (in Czech), Prague, Grada Publishing, p. 196. ISBN 80-247-0569-9.

[17] Zairi, M. and Sinclair, D. (1995) "Business process re-engineering and process management", Business Process Management Journal, Vol. 1, No. 1, pp. 161-173. ISSN 1463-7154. DOI 10.1108/14637159510798248. 